\title{
EFFECTS OF METABOLIZABLE ENERGY AND LYSINE ON GROWTH AND FEED CONVERSION RATIO OF H'MONG BROILERS AT O TO 4 WEEK - AGE
}

\author{
L. T. Hung ${ }^{1}$, V. V. Son ${ }^{2}$, and N. T. $\mathrm{Ngu}^{3}$
}

\begin{abstract}
An experiment was conducted to evaluate the interactive influences of dietary $M E$ and lysine on growth of H'mong broilers from 0 to 28 days of age. The study was in a $3 \times 3$ two-factorial design, with the first factor being 3 levels of $\mathrm{ME}(3,000 ; 3,100$ and 3,200 $\mathrm{kcal} / \mathrm{kg}$ of feed) and the second one being 3 levels of lysine $(1.1 \% ; 1.0 \%$ and $0.9 \%)$, and 4 replicates with 6 broilers for each. Two hundreds and sixteen broilers were placed into 36 bamboo floor pens (6 birds/pen). The diets were formatted from corn yellow, soybean meal, soybean oil, DCP, shell, mineral and vitamin premixes, salt, and some of synthetic essential amino acids. Chicks were fed ad libitum and provided water all of time. The feeding trial was lasted for 4 weeks. The result indicated that the ME 3,000 kcal/kg of feed and lysine $1.1 \%$ diet resulted in the most efficient feed conversion ratio.
\end{abstract}

Keywords: metabolizable energy, lysine, H'mong broiler, growth, feed conversion ratio.

\section{INTRODUCTION}

Local H'mong chickens with black skin, bone and meat [1] and their meat contains high lysine and methionine giving it good taste when consumed [2].

Like other variety of chicken breeds, growth and development of H'mong broilers depend on several factors, especially metabolizable energy (ME) and protein of diets, which play a very important role. D'Mello [3] indicated that when CP content increases from 140 to $280 \mathrm{~g} / \mathrm{kg}$ of diet, there is a marked and progressive reduction

\footnotetext{
${ }^{1}$ School of Agriculture and Aquaculture, Tra Vinh University, Vietnam

${ }^{2}$ Vietnam Vemedim Corporation

${ }^{3}$ College of Agriculture and Applied Biology, Can Tho University, Vietnam

Email: 1thung@tvu.edu.vn

Received date: $07^{\text {th }}$ November 2016; Revised date: $12^{\text {th }}$ May 2017; Accepted date: $23^{\text {rd }}$ July 2018
}

in the efficiency in use of the first-limiting amino acid (AA), lysine. Supplementation of protein for feed using efficiency on birds' growth belongs to better balanced essential AAs in the diets [4]. Moreover, the animal body only synthesizes proteins from patterns of balanced AAs and if unlimited AAs are provided, the diets will have unbalanced AAs. Birds' growth performance has maintained when essential AAs were supplied in the low-protein diets [5]. Besides, other studies have indicated that low-protein diets but adequate AAs still supported best for broilers' feed intake and growth ability [6]-[9].

Lysine is used as a reference AA for calculating ideal ratios, because it is a limited essential AA. Therefore, ideal AA ratios, with lysine as the reference AA, are being increasingly used throughout the world for diet formulation of poultry today [10]-[15]. Mack et al. [14] also found that the lysine requirement for maximal feed efficiency was substantially higher than that required for maximal weight gain. Hence, the lysine content of the diets was calculated according to high levels to investigate the growth performance of H'mong broiler breed in this study.

Supplementation of synthetic essential AAs in the low-protein diets has also restricted enviromental pollution by nitrogen [16]. Thus, the purpose of this study is to determine the effects of $\mathrm{ME}$ and lysine on growth of H'mong broilers from 0 to 4 weeks of age.

\section{MATERIALS AND METHODS}

Animals and experimental design: two hundreds and sixteen 0-day-old H'mong chicks were allocated into nine treatments in $3 * 3$ factorials, 4 replicates, and 6 birds for each experimental unit. The first factor consisted of 3 levels of ME $(3,000 ; 3,100 ; 3,200 \mathrm{kcal} / \mathrm{kg}$ of feed) and the second factor was of 3 levels of lysine $(0.9 \%$; 
$1.0 \% ; 1.1 \%)$. Methionine + cystine, threonine, and tryptophan followed the AA ideal profile of Baker [12]. All birds were raised in bamboo floor cages, continuous lighting, natural ventilation, and $27-30^{\circ} \mathrm{C}$ of ambient temperature. The diets were offered ad libitum and water was freely available throughout the four-week trial.

Feed analyses and calculations: The feedstuffs were analyzed for dry matter (DM), crude protein $(\mathrm{CP})$, crude fibre $(\mathrm{CF})$, ether extract $(\mathrm{EE})$, ash, calcium, and phosphorus by standard Weende methods [17] at the College of Agriculture and Applied Biology - Can Tho University. ME of soybean oil (SBO) was calculated by formulation of Ketels and DeGroote [18] $M E=8.227-$

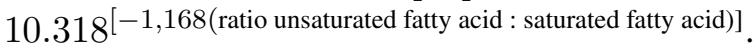

AA contents were analyzed in Laboratory department of Animal nutrition - Institute of Agricultural Science for Southern Viet Nam. ME content of the feedstuffs was calculated from chemical analysis data using the equation of Kinh [19]. Yellow corn (YC): ME ( $\mathrm{kcal} / \mathrm{kg}$ of feed $)=19.0+37.5 \mathrm{CP}+78.5 \mathrm{EE}+11.2 \mathrm{CF}+$ 37.7 NFE.

Soybean meal $(\mathrm{SBM}): \mathrm{ME}(\mathrm{kcal} / \mathrm{kg}$ of feed $)=$ $-2.7+35.1 \mathrm{CP}+96.7 \mathrm{EE}-4.2 \mathrm{CF}+28.6 \mathrm{NFE}$.

Data collection: Birds were weighed to evaluate bodyweight gain (BWG) and feed was weighed to calculate their feed consumption every week. Weight, feed intake (FI), and feed conversion ratio (FCR) ( $\mathrm{g}$ of feed/g of BWG) were measured for each week.

Data analysis: Analysis of variance was calculated with the General Linear Model procedure (GLM) in Minitab 13.2 [20].

\section{RESULTS AND DISCUSSION}

Effects of dietary ME on BWG, FI, and FCR of broilers: Table 3 shows that daily feed, ME, $\mathrm{CP}$, and lysine intake; daily BWG; and FCR were significantly different among broilers in diets of three different dietary ME levels. The results of ME intake daily of birds decreased when the dietary ME was over 3,000 kcal/kg of feed. This finding is similar to the report by Lung and Man [21] that birds' FI was a negative correlation with the ME level of diets.

Summers [22] demonstrated that dietary energy concentration strongly influenced in FI, or the daily FI of birds negatively correlated with $\mathrm{ME}$ in the diets. Birds also decreased FI after obtaining adequate energy for their requirement [23]. Moreover, FI of broilers will decrease when the ME-containing diets increased from 2,600 to $3,200 \mathrm{kcal} / \mathrm{kg}$ of feed [24]. The amount of FI of H'mong broilers was equivalent to that of FI of 0-4 week-old broilers imported from Egypt at 10$34 \mathrm{~g} / \mathrm{bird} /$ day in the researching result of Dat et al. [25]; at 10-34 g/bird/day in the study of Tam [26].

H'mong broilers consumed higher feed in treatments containing 3,000 kcal $/ \mathrm{kg}$ of feed but lower ME compared to others. Previously, it was found that broilers still have good ability to control its FI based on desire requirement to normalize FI and to regulate its FI to supply for the lacks of dietary ME changes [27],. Moreover, Loi [28] found that ME consumed by local Ac broilers in high-ME-diets was higher than that of low ME diets because of the difference between ME of diets. However, ME consumed by H'mong broilers was 45.04-46.88 $\mathrm{kcal} / \mathrm{bird} / \mathrm{day}$, which was lower than that consumed by broilers imported from Egypt at 53.7-55.5 kcal/bird/day [26].

Dozier et al. [29] pointed that caloric intake did not differ as dietary available ME increased because the broilers were able to adjust feed consumption abilities to achieve the similarity of caloric intake when provided diets varying in available ME. Therefore, caloric consumption per unit of BWG decreased as available dietary ME increased, but caloric intake per unit of total white meat was not affected by the dietary ME. In the current research, H'mong broilers adjusted the amount of FI in the diets varying ME to balance energy consumption, but broilers' feed consumption was only regulated relatively.

In addition, CP consumption reduced when progressively increasing ME of diets. This was because $\mathrm{CP}$ concentrations of diets were similar, the broilers decreasingly ingested resulting in reduced $\mathrm{CP}$ consumption. H'mong's daily $\mathrm{CP}$ intake was lower than that of broilers imported from Egypt at 3.9-4.02 g/bird/day [26]. Moreover, because there was difference of feed consumption among treatments, the amount of lysine was differently consumed by H'mong broilers.

Therefore, the birds' BWG tended to reduce as they were provided with diets above 3,000 $\mathrm{kcal} / \mathrm{kg}$ of feed. The BWG of H'mong was closely positive correlated to its consumed lysine $(r=$ 
Table 1: Chemical compositions of feedstuffs

\begin{tabular}{|c|c|c|c|c|c|c|c|c|c|c|c|}
\hline \multirow{2}{*}{ Feedstuffs } & \multirow{2}{*}{$\mathrm{DM}(\%)$} & \multicolumn{10}{|c|}{ Chemical compositions of feedstuffs ( $\%$ of feed) } \\
\hline & & $\mathrm{CP} \mid \mathrm{I}$ & $\mathrm{cal} / \mathrm{kg})$ & $\mathrm{EE}$ & $\mathrm{CF}$ & Lys & Met+cys & Thr & $\operatorname{Trp}$ & $\mathrm{Ca}$ & $\mathrm{P}$ \\
\hline $\mathrm{YC}$ & 86.90 & 7.59 & 3,236 & 3.31 & 4.84 & 0.21 & 0.28 & 0.25 & 0.05 & 0.63 & 0.29 \\
\hline SBM & 87.50 & 42.74 & 2,512 & 2.35 & 7.35 & 2.23 & 1.14 & 1.51 & 0.52 & 0.63 & 0.67 \\
\hline SBO & & & 8,227 & & & & & & & & \\
\hline DCP & & & -1 & - & - & - & & -1 & & 24.11 & 19.29 \\
\hline Sell & - & -1 & -1 & - & - & 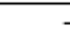 & & -1 & & 29.22 & \\
\hline
\end{tabular}

Table 2: Diets and their nutrient values

\begin{tabular}{|c|c|c|c|c|c|c|c|c|c|}
\hline \multirow[b]{3}{*}{ Feedstuffs (kg) } & \multicolumn{3}{|c|}{$\mathrm{ME} 3,000 \mathrm{kcal}$} & \multicolumn{3}{|c|}{ ME $3,100 \mathrm{kcal}$} & \multicolumn{3}{|c|}{ ME $3,200 \mathrm{kcal}$} \\
\hline & Lysine & Lysine & Lysine & Lysine & Lysine & Lysine & Lysine & Lysine & Lysine \\
\hline & $0.9 \%$ & $1 \%$ & $1.1 \%$ & $0.9 \%$ & $1 \%$ & $1.1 \%$ & $0.9 \%$ & $1 \%$ & $1.1 \%$ \\
\hline $\mathrm{YC}$ & 56.18 & 55.81 & 56.06 & 54.49 & 53.25 & 53.52 & 54.17 & 53.40 & 52.99 \\
\hline SBM & 38.45 & 38.6 & 38.03 & 37.97 & 38.9 & 38.36 & 36.56 & 36.99 & 37.00 \\
\hline SBO & 2.48 & 2.58 & 2.65 & 4.5 & 4.71 & 4.77 & 6.24 & 6.42 & 6.57 \\
\hline L-Lysine- $\mathrm{HCl}$ & - & 0.03 & 0.14 & - & 0.03 & 0.14 & - & 0.10 & 0.17 \\
\hline DL-Methionine & 0.06 & 0.13 & 0.20 & 0.06 & 0.13 & 0.20 & 0.09 & 0.15 & 0.22 \\
\hline L-Threonine & - & & 0.03 & - & - & 0.03 & - & - & 0.05 \\
\hline DCP & 2.00 & 2.02 & 2.02 & 2.15 & 2.15 & 2.15 & 2.11 & 2.11 & 2.17 \\
\hline Sell & 0.10 & 0.10 & 0.14 & 0.10 & 0.10 & 0.10 & 0.10 & 0.10 & 0.10 \\
\hline Premix & 0.25 & 0.25 & 0.25 & 0.25 & 0.25 & 0.25 & 0.25 & 0.25 & 0.25 \\
\hline Salt & 0.48 & 0.48 & 0.48 & 0.48 & 0.48 & 0.48 & 0.48 & 0.48 & 0.48 \\
\hline Total & 100 & 100 & 100 & 100 & 100 & 100 & 100 & 100 & 100 \\
\hline \multicolumn{10}{|l|}{ Nutrient value (\%) } \\
\hline ME (kcal/kg of feed) & 2,987 & 2,987 & 2,987 & 3,087 & 3,087 & 3,087 & 3,185 & 3,185 & 3,185 \\
\hline $\mathrm{CP}$ & 20.76 & 20.89 & 20.88 & 20.42 & 20.82 & 20.83 & 19.83 & 20.11 & 20.77 \\
\hline $\mathrm{EE}$ & 5.24 & 5.33 & 5.40 & 7.20 & 7.38 & 7.44 & 8.89 & 9.05 & 9.19 \\
\hline $\mathrm{CF}$ & 5.55 & 5.54 & 5.51 & 5.43 & 5.44 & 5.41 & 5.31 & 5.30 & 5.28 \\
\hline $\mathrm{Ca}$ & 1.10 & 1.11 & 1.12 & 1.13 & 1.12 & 1.12 & 1.11 & 1.10 & 1.11 \\
\hline $\mathrm{P}$ & 0.81 & 0.81 & 0.81 & 0.83 & 0.83 & 0.83 & 0.81 & 0.81 & 0.82 \\
\hline Lysine & 0.90 & 1.00 & 1.10 & 0.90 & 1.00 & 1.10 & 0.90 & 1.00 & 1.10 \\
\hline Met+cys & 0.65 & 0.72 & 0.79 & 0.65 & 0.72 & 0.79 & 0.65 & 0.72 & 0.79 \\
\hline Threonine & 0.72 & 0.72 & 0.74 & 0.71 & 0.72 & 0.74 & 0.68 & 0.69 & 0.74 \\
\hline Tryptophan & 0.22 & 0.23 & 0.20 & 0.22 & 0.23 & 0.22 & 0.22 & 0.22 & 0.22 \\
\hline
\end{tabular}

0.842) meaning that when decreasing lysine consumption, broilers obtained lower BWG. As the dietary ME also contained over 3,000 kcal/ $\mathrm{kg}$ of feed, FI of broilers was limited. This resulted in decreasing some of the consumed nutrients in the diet, especially lysine contents.

H'mong broilers had higher ratio of dietary lysine to ME of the diet containing $3,000 \mathrm{kcal} / \mathrm{kg}$ of feed attained, as compared to that in the diets containing 3,100 and 3,200 kcal/kg of feed. Similarly, the findings of Kerr et al. [30]; Labadan et al. [31]; and Mbajiorgu et al. [32] found that the ratio of dietary lysine to energy did not have significant effects on feed intake, nitrogen digestiblity, and $\mathrm{ME}$ intake, but the high-ratio diets supported for optimum of growth rate and FCR.
Birds' greater FI in the higher-CP diets was found by Sengar [33] but that was opposite to the report of Waldroup et al. [24] in which low$\mathrm{CP}$ diets significantly depressed appetite. Broilers increasingly fed at about ME levels (from 2,600 to $3,200 \mathrm{kcal} \mathrm{ME} / \mathrm{kg}$ ) showed no significant effects on performance parameters, although there was a decrease in FI and an improvement in feed conversion with increasingly dietary ME levels [24].

On the other hand, Holsheimer and Veerkamp [34] reported that BWG was $4.2 \%$ higher and feed conversion was $12.1 \%$ higher with increasing levels of ME. Performance parameters showed a linear increasing response when levels of 3,200; 3,400 and 3,600 kcal ME/kg were used for broiler chickens during the finishing phase 
Table 3: Effects of ME on BWG, FI, and FCR of birds

\begin{tabular}{|l|r|r|r|r|r|}
\hline \multirow{2}{*}{ Terms } & \multicolumn{3}{|c|}{ Levels of ME (kcal/kg of feed) } & & \\
\cline { 2 - 4 } & 3,000 & 3,100 & 3,200 & SEM & P \\
\hline FI daily (g/bird) & $15.08^{\mathrm{a}}$ & $15.19^{\mathrm{a}}$ & $14.64^{\mathrm{b}}$ & 0.09 & 0.001 \\
\hline ME intake D (kcal/bird) & $45.04^{\mathrm{b}}$ & $46.88^{\mathrm{a}}$ & $46.63^{\mathrm{a}}$ & 0.27 & 0.001 \\
\hline CP intake D (g/bird) & $3.14^{\mathrm{a}}$ & $3.14^{\mathrm{a}}$ & $2.94^{\mathrm{b}}$ & 0.02 & 0.001 \\
\hline Lysine intake D (g/bird) & $0.152^{\mathrm{a}}$ & $0.153^{\mathrm{a}}$ & $0.147^{\mathrm{b}}$ & 0.001 & 0.001 \\
\hline L/ME ratio intake (g/Mcal) & 3.370 & 3.261 & 3.161 & - & - \\
\hline Initial BW (g/bird) & 28.37 & 28.40 & 28.37 & 0.14 & 0.98 \\
\hline Final BW (g/bird) & $193^{\mathrm{a}}$ & $190^{\mathrm{b}}$ & $182^{\mathrm{c}}$ & 0.67 & 0.001 \\
\hline BWG daily (g/bird) & $5.90^{\mathrm{a}}$ & $5.77^{\mathrm{b}}$ & $5.48^{\mathrm{c}}$ & 0.03 & 0.001 \\
\hline FCR & $2.44^{\mathrm{b}}$ & $2.50^{\mathrm{a}}$ & $2.49^{\mathrm{a}}$ & 0.01 & 0.001 \\
\hline
\end{tabular}

$a, b$, and $c:$ Means within each row with the same superscript letter are not significantly different (P > 0.05); D: daily, BW: bodyweight, L: lysine

[35]. These findings were collected on broilers with high growth and good feed conversion ability, the broilers gained better with increasing dietary ME exceeding 3,200 $\mathrm{kcal} / \mathrm{kg}$ of feed. Conversely, as H'mong chicken breed is of low growth, they were raised by the diets over 3,000 $\mathrm{kcal} \mathrm{ME} / \mathrm{kg}$ of feed that resulted in decreasing FI and BWG.

The current BWG of H'mong at 4 weeks was equivalent to the investigating results of Van et al. [36]. However, it was lower than the findings of Van [37] and Hong et al. [2]. FCR of broilers differed signicantly and FCR increased when ME of diets was above $3,000 \mathrm{kcal} / \mathrm{kg}$ of feed. Birds' FCR of this research was lower than that of Van [37]; Quyen and Son [38]. This implied that if diets are balanced well, especially lysine, feed using efficency will be better.

Effects of dietary lysine on BWG, FI, and FCR of broilers: In Table 4, it is shown that feed, ME, and CP intake were not significantly different among trials. This indicated that increasing of dietary lysine from $0.9 \%$ to $1.1 \%$ did not change feed, ME, and CP intake. Lysine is a basal unit of protein and adding lysine to balance diets will also supply dietary CP. Hence, when supplying lysine into the dietary with fixed CP, FI was not influenced. The result also showed a low correlation ratio between lysine intake and feed consumption $(r=0.258)$. The study was likely in line with the report of Araújo et al. [39] that when supplying $0.95 \%$; $1.05 \%$; and $1.15 \%$ lysine into the diets, the feed consumption of broilers did not change.

However, lysine intake, BWG, and FCR of
H'mong were significantly different and the amount of lysine intake also correlated closely with H'mong's BWG $(r=0.842)$. Moreover, increasing the amount of dietary lysine resulted in higher lysine/ME ratio and hence improving BWG.

Besides, as lysine is an AA to calculate other essential AAs following an ideal AA pattern, a little change of lysine content only influenced broilers' BWG. This was similar to the results of Baker et al. [15] that the broilers' diet containing $1.27 \%$ lysine had more BWG than that of $0.84 \%$ lysine. Also, Kidd et al. [40] supplied lysine to the broilers' diet at $105 \%$ compared with the requested level of Skinner et al. [41], recieved better BWG. Han and Baker [42] demonstrated that the more dietary lysine content supplied the better broilers' yield and carcass. Conversely, if broilers were raised by diets being lack of lysine, the birds' BWG reduced $45 \%$ compared with birds which were raised by diets with normal lysine levels [43]. Parr and Summers [6] also indicated that adding 10\% lysine to the diets containing normal lysine requirement did not change growth performance of broilers.

Moreover, the correlation ratio between consumed lysine and FCR was -0.81 and this indicated that the ratio had closely negative correlation. This finding confirmed the results of Araújo et al. [39]; Han and Baker [42]; and Kidd et al. [40], which pointed out that the increased dietary lysine resulted in improved feed consumption efficiency of broilers. FCR of 14 old-day broilers was also better in excessive AA diets [41], [44], [45] and supplement of AAs in high levels will 
Table 4: Effects of dietary lysine on BWG, nutrient intake, and FCR of birds

\begin{tabular}{|l|r|r|r|r|r|}
\hline & \multicolumn{3}{|c}{ Levels of lysine (\%) } & \multirow{2}{*}{ SEM } & \multirow{2}{*}{ P } \\
\cline { 2 - 5 } Terms & 0.9 & 1.0 & 1.1 & & \\
\hline FI daily (g/bird) & 15.03 & 14.86 & 15.01 & 0.09 & 0.32 \\
\hline ME intake D (kcal/bird) & 46.39 & 45.83 & 46.33 & 0.27 & 0.30 \\
\hline CP intake D (g/bird) & 3.06 & 3.06 & 3.10 & 0.02 & 0.18 \\
\hline Lysine intake D (g/bird) & $0.135^{\mathrm{c}}$ & $0.150^{\mathrm{b}}$ & $0.167^{\mathrm{a}}$ & 0.001 & 0.001 \\
\hline L/ME ratio intake (g/Mcal) & 2.918 & 3.275 & 3.599 & - & - \\
\hline Initial BW (g/bird) & 28.31 & 28.46 & 28.37 & 0.14 & 0.75 \\
\hline Final BW (g/bird) & $181^{\mathrm{c}}$ & $186^{\mathrm{b}}$ & $198^{\mathrm{a}}$ & 0.67 & 0.001 \\
\hline BWG daily (g/bird) & $5.45^{\mathrm{c}}$ & $5.64^{\mathrm{b}}$ & $6.05^{\mathrm{a}}$ & 0.03 & 0.001 \\
\hline FCR & $2.60^{\mathrm{a}}$ & $2.50^{\mathrm{b}}$ & $2.34^{\mathrm{c}}$ & 0.01 & 0.001 \\
\hline
\end{tabular}

$a, b$, and $c$ : Means within each row with the same superscript letter are not significantly different (P > 0.05); D: daily, BW: bodyweight, L: lysine

ensure to provide AAs adequately. In addition, when the lysine content of diets increased, the FI of broilers consumed was lower, but bird's bodyweight did not change due to higher feed using efficiency [42]. As the level of dietary lysine increased $0.1 \%$ compared with the basal diet, BWG of birds was added more $0.19 \mathrm{~g} / \mathrm{bird} /$ day, but FCR decreased $0.1 \mathrm{~kg}$ of feed over $\mathrm{kg}$ of BWG.

Effects of dietary ME and lysine on BWG, FI, and FCR of broilers: In Table 5, it is shown that feed, ME, CP, and lysine intake did not differ significantly. In contrast, the final bodyweight of birds was significantly different. This pointed out that there was an interaction between dietary ME and lysine. The present data supported the report of Boomgaardt and Baker [46], where broilers consumed lower lysine in high ME diets resulting in reducing BWG that did not influence lysine using efficiency. Leeson and Summers [47] pointed out that if diets contain adequately essential AAs, growth and development of birds would be good in the most sensible ME consumption. H'mong's BWG of the current study was higher than that of Noi birds of Quyen [48], similar to that observed by Van et al. [36], and lower than that result of Van [37].

The study also showed that diets containing three levels of ME interacting with 3 levels of lysine made significant difference of birds' FCR. With value of $\mathrm{P}<0.01$ and delimitated analyzing results of treatment pairs, it was demonstrated that the main impact factor was the interaction between ME and lysine. FCR of H'mong of this study was lower than the research findings of Quyen and Son [38] that FCR of Noi broilers was 2.96-4.42 when birds were raised by the diets mainly based on ME and crude protein.

\section{CONCLUSION}

0-4 week-age H'mong broilers should be raised by the diet containing ME 3,000 kcal/ $\mathrm{kg}$ of feed and lysine $1.1 \%$ for better obtaining BWG and FCR.

\section{REFERENCES}

[1] DAO D T A, DUC V T. Researching appearance and behavioral characteristics of H'mong chickens semiindustrial bred and grazing farmed in Thuan Chau Son La. J Anim Husb Sci Tech. 2011;152:17-26.

[2] HONG L T, THIEU P C, TIEU H V, THAI N V. Study on productivity of cross-bred H'Mong x Ai Cap chicken. J Anim Husb Sci Tech. 2011;8:8-15.

[3] D'MELLO J P F. Responses of growing poultry to amino acids. In: amino acids in animal nutrition. D'Mello JPF, editor. Formerly of the Scottish Agricultural College. CABI Publishing., Edinburgh, UK; 2003.

[4] NGOAN L Đ, LY N T H, HANG D T T. Curriculum of Animal feed. Hue Univ. Agr. Fore, Vietnam; 2004.

[5] MORAN E T J, BUSHONG R D, BILGILI S F. Reducing dietary crude protein for broilers while satisfying amino acid requirements by least-cost formulation: live performance, litter composition, and yield of fast-food carcass cuts at six weeks. Poul Sci. 1992;71:1687-1694.

[6] PARR J F, SUMMERS J D. The effect of minimizing amino acid excesses in broiler diets. Poul Sci. 1991;70:1540-1549.

[7] DESCHEPPER K, DEGROOTE G. Effect of dietary protein, essential and non-essential amino acids on the performance and carcass composition of male broiler chickens. Bri Poul Sci. 1995;36:229-245. 
Table 5: Effects of ME and lysine of diets on BWG, nutrient intake, and FCR of birds

\begin{tabular}{|c|c|c|c|c|c|c|c|c|c|c|c|}
\hline Factors & \begin{tabular}{|r|} 
ME 3 \\
feed in \\
ler
\end{tabular} & $\begin{array}{l}00 \mathrm{kc} 2 \\
\text { ractin }\end{array}$ & $\begin{array}{l}\mathrm{kg} \text { of } \\
\text { with } 3 \\
\text { ine }\end{array}$ & $\begin{array}{r}\text { ME 3, } \\
\text { feed in } \\
\text { lev }\end{array}$ & & & $\begin{array}{r}\text { ME 3 } \\
\text { feed in } \\
\text { lev }\end{array}$ & & & & \\
\hline Terms & $0.9 \%$ & $1.0 \%$ & $1.1 \%$ & $0.9 \%$ & $1.0 \%$ & $1.1 \%$ & $0.9 \%$ & $1.0 \%$ & $1.1 \%$ & SEM & $p$ \\
\hline FId & 15.05 & & & & & & & & & 0.15 & 0.67 \\
\hline (kcal/bird) & 44.97 & 45.13 & 45.02 & 47.08 & & 47.27 & 47.12 & 46.07 & 46.69 & & 0.66 \\
\hline illy (g/bird) & 3.13 & 3.16 & 3.15 & 3.11 & 3.13 & 3.19 & 2.93 & 2.91 & 2.97 & 0.03 & 0.69 \\
\hline Lysine intake daily ( $g /$ bird) & 0.136 & 0.153 & 0.167 & 0.137 & 0.152 & 0.170 & 0.133 & 0.146 & 0.163 & 0.002 & 0.56 \\
\hline $\begin{array}{l}\text { Lysine/ME } \\
(\mathrm{g} / \mathrm{Mcal})\end{array}$ & 3.013 & 3.381 & 3.716 & 2.915 & 3.272 & 3.596 & 2.826 & 3.171 & 3.485 & & \\
\hline odyweight (g/bird) & 28.33 & 28.35 & 28.43 & 28.33 & 28.55 & 28.33 & 28.28 & 28.48 & 28.35 & 0.24 & 0.98 \\
\hline (g/bird) & $182^{\mathrm{ef}}$ & $190^{c}$ & $208^{\mathrm{a}}$ & $183^{\mathrm{de}}$ & $189^{\text {cd }}$ & $198^{b}$ & $177^{\mathrm{i}}$ & $180^{\mathrm{eff}}$ & $188^{\text {cd }}$ & 1.16 & 0.001 \\
\hline BWG & $5.50^{\mathrm{ef}}$ & $5.77^{\mathrm{c}}$ & $6.41^{\mathrm{a}}$ & $5.54^{\mathrm{de}}$ & $5.73^{\text {cd }}$ & $6.04^{b}$ & $5.32^{\mathrm{f}}$ & $5.42^{\mathrm{ef}}$ & $5.70^{\text {cd }}$ & 0.04 & 0.001 \\
\hline FCR & $2.61^{\mathrm{a}}$ & $2.51^{\mathrm{b}}$ & $2.21^{\mathrm{d}}$ & $2.61^{\mathrm{a}}$ & $2.49^{b}$ & $2.40^{c}$ & $2.59^{\mathrm{a}}$ & $2.49^{6}$ & $2.41^{\mathrm{c}}$ & 0.02 & 0.001 \\
\hline
\end{tabular}

$a, b$, and $c:$ Means within each row with the same superscript letter are not significantly different $(P>0.05)$

[8] YAMAZAKI M, MURAKAMI H, TAKEMASA M. Effects of ratios of essential amino acids to nonessential amino acids in low protein diet on excretion and fat deposition of broiler chicks. Jap Poul Sci. 1998;35:19-26.

[9] ALETOR V A, HAMID I I, NIESS E, PFEFFER E. Low-protein amino acid-supplemented diets in broiler chickens: effects on performance, carcass characteristics, whole-body composition and efficiencies of nutrient utilization. J Sci Foo Agr. 2000;80:547-554.

[10] BAKER D H, HAN Y. Ideal amino acid profile for broiler chicks during the first three weeks posthatching. Poul Sci. 1994;73:1441-1447.

[11] NRC (NATIONAL RESEARCH COUNCIL). Nutrient Requirements of Poultry. 9th ed. National Academy Press. Washington, DC; 1994.

[12] BAKER D H. Ideal amino acid profiles for swine and poultry and their applications in feed formulation. Biokyowa Tech Rev. 1997;9:1-24.

[13] EMMERT J L, BAKER D H. Use of the ideal protein concept for precision formulation of amino acid levels in broiler diets. J Appl Poul Res. 1997;6:462-470.

[14] MACK S, BERCOVICI D, DEGROOTE G, LECLERCQ B, LIPPENS M, PACK M, et al. Ideal amino acid profile and dietary lysine specification for broiler chickens of 20 to 40 days of age. Bri Poul Sci. 1999;40:257-265.

[15] BAKER D H, BATAL A B, PARR T M, AUGSPURGER N R, PARSONS C M. Ideal ratio (relative to lysine) of tryptophan, threoninee, isoleucine and valine for chicks during the second and third week of life. Poul Sci. 2002;81:485-494.

[16] CORZO A, KIDD M T, BURNHAM D J, MILLER E R, BRANTON S L, GONZALEZ ESQUERRA R. Dietary amino acid density effects on growth and carcass of broilers differing in strain cross and sex. $J$ Appl Poul Res. 2005;14:1-9.

[17] AOAC. Official Methods of Analysis. In: Association of official Analytical Chemists. vol. 1. 15th ed. Washington DC; 1990. p. 69-90.

[18] KETELS E, DEGROOTE G. Effects of ratio of unsaturated fatty acids of the dietary lipid fraction on utilization and metabolizable energy of added fats in young chicks. Poul Sci. 1989;68:1506.

[19] KINH L V. Chemical composition and nutritive value of feedstuffs in Vietnam. Agr. 2003;68:122. Publisher in Ho Chi Minh city.

[20] MINITAB. Minitab Reference Manual. Minitab Inc, State College, PA; 2000. PC Version, Release 13.2.

[21] LUNG B D, MAN L H. Feed and poultry raising. Agr. 2001;Ha Noi, Vietnam.

[22] SUMMERS J D. Energy in poultry diets. Ministry of Agr. 2000; Food and Rural Affairs. Ontario.

[23] LIEM D T. Curriculum of poultry raising technique. Ho Chi Minh Univ. Agr. 2003; Vietnam.

[24] WALDROUP P W, TIDWELL N M, IZAT A L. The effects of energy and amino acid levels on performance and carcass quality of male and female broilers grown separately. Poul Sci. 1990;69:15131521. Vietnam.

[25] DAT N H, HUNG V T, TUNG H X, THIEN V C. Study on productivity of cross-bred between Egypt chickens and straw-yellow Ri in semi-scavenge condition. J Sci Tech. 2008;10:37-44. Vietnam.

[26] TAM T V. Effects of feedstuffs on growth of Egypt chickens from 0 to 15 age-week in Soc Trang poultry breeding center [M Sci Thesis]. Can Tho Univ., Vietnam; 2008.

[27] LEESON S, CASTON L, SUMMERS J D. Broiler responses to diet energy. Poul Sci. 1996;75:529-535.

[28] LOI N H. Effects of crude protein levels and metabolizable energy on growth and nutrient digestible ratio of Ac chickens [M Sci Thesis]. Can Tho Univ, Vietnam; 2009.

[29] DOZIER W A III, PRICE C J, KIDD M T, CORZO A, ANDERSON J, BRANTON S L. Growth performance, meat yield, and economic responses of broilers fed diets varying in metabolizable energy from thirty to fifty-nine days of age. J Appl Poul Res. 2006;15:367-382.

[30] KERR B J, KIDD M T, HALPIN K M, WARD G W MC, QUARLES C L. Lysine level increases live 
performance and breast yield in male broilers. $J$ Appl Poul Res. 1999;8:381-390.

[31] LABADAN JR, M C, HSU K N, AUSTIC R E. Lysine and arginine requirements of broiler chickens at two to three-week intervals to eight weeks of age. Poul Sci. 2001;80:599-606.

[32] MBAJIORGU C A, NG'AMBI J W, NORRIS D, ALABI O J. Effect of dietary lysine to energy ratio on performance of unsexed indigenous Venda chickens. Asia J Anim Vet Adv. 2011;5:517-524.

[33] SENGAR S S. Feed intake and growth rate pattern in White Leghorn chicks maintained on different planes of nutrition. Poul Advi. 1987;20:23-27.

[34] HOLSHEIMER J P, VEERKAMP C H. Effect of dietary energy, protein, and lysine content on performance and yields of two strains of male broiler chicks. Poul Sci. 1992;71:872-879.

[35] PESti G M, WhITING T S, JENSEN L S. The effect of crumbling on the relationship between dietary density and chicken growth, feed efficiency, and abdominal fat pad weights. Poul Sci. 1983;62:490 494.

[36] VAN T T, MY N T T, SINH N V. The current status of chicken breeding and specifications of H'mong chicken breed at some districts of upland and mountainous regions of Hagiang province. J Agr R Dev. 2006;20:83-85.

[37] VAN T T. The growth H'mong black color chicken keeping at household in Thai Nguyen. J Agr R Dev. 2005;2:54-56.

[38] QUYEN N V, SON V V. The influences of energetic lavels and gross protein on growth of garden raising Noi chicken breeding in period of $0-8$ weeks in Mekong delta. J Agr R Dev. 2008;5:58-61.

[39] ARAÚJO L F, JUNQUEIRA O M, ARAÚJO C S S, BARBOSA L C G S, ORTOLAN J H, FARIA D E, et al. Energy and lysine for broilers from 44 to 55 days of age. Bra J Poul Sci. 2005;4:237-241.

[40] KIDD M T, KERR B J, ANTHONY N B. Dietary interactions between lysine and threonine in broilers. Poul Sci. 1997;76:608-614.

[41] SKINNER J T, WALDROUP A L, WALDROUP $\mathrm{P}$ W. Effects of dietary amino acid level and duration of finisher period on performance and carcass content of broilers forty-nine days of age. Poul Sci. 1992;71:1207-1214.

[42] HAN Y, BAKER D H. Effects of sex, heat stress, body weight and genetic strains on the dietary lysine requirement of broiler chicks. Poul Sci. 1991;72:701708.

[43] TESSERAUD S, MAA N, PERESSON R, CHAGNEAU A M. Relative responses of protein turnover in three different skeletal muscles to dietary lysine deficiency in chicks. Br Poul Sci. 1996;37:641-650.

[44] CORZO A, MORAN E T, HOEHLER J D, LEMME A. Dietary tryptophan need of broiler males from forty-two to fifty-six days of age. Poul Sci. 2004;84:226-231.

[45] BARTOV I, PLAVNIK I. Moderate excess of dietary protein increases breast meat yield of broiler chicks. Poul Sci. 1998;77:680-688.
[46] BOOMGAARDT J, BAKER D H. Effect of dietary energy concentration on sulphur amino acid requirements and body composition of young chicks. J Anim Sci. 1973;36:307-311.

[47] LEESON S, SUMMERS J D. Response of Leghorn pullets to protein and energy in the diet when reared in regular or hot-cyclic environments. Poul Sci. 1973;68:546-557.

[48] QUYEN N V. Researching effects of metabolizable energy and crude protein on sex developing and egg layer ratio of Noi chicken in Mekong delta [Agr]. Can Tho Univ, Vietnam; 2008. 